\section{Response of Young Pecan Trees to Irrigation in a Humid Climate}

\author{
Lenny Wells ${ }^{1}$ \\ Department of Horticulture, University of Georgia, Tifton Campus, 4604 \\ Research Way, Tifton, GA 31793
}

Additional index words. Carya illinoinensis, water use, stem water potential, leaf area, orchard establishment

Abstract. The prolonged period from tree planting to first commercial harvest of pecan
[Carya illinoinensis (Wangenh.) K. Koch] provides incentive for many growers to intensively
manage young trees to induce commercial production as soon as possible. This management
includes irrigation. However, there remain very few data regarding the irrigation re-
quirements of young pecan trees grown under southeastern U.S. orchard conditions. The
objectives of this study were to determine appropriate irrigation rates for young pecan trees
and to compare growth of young pecan trees with drip and microsprinkler irrigation.
Parameters evaluated for both experiments include trunk diameter growth, stem water
potential (water stress), leaf area, leaf length, leaf width, and chlorophyll index. These results
suggest that irrigation is beneficial to the growth, vigor, and alleviation of water stress on
young pecan trees in the establishment phase grown in the temperate region of the
southeastern United States. There was no difference in young pecan tree growth and vigor
for microsprinkler irrigated trees at $304 \mathrm{~L}$ per week (lpw) compared with 650 lpw from the
year of planting through the third leaf. Similarly, drip irrigation at 182 lpw appears to result
in equal tree growth compared with both drip and microsprinkler irrigation at over 600 lpw.

Recent pecan price increases have renewed interest in the crop and led to the planting of additional pecan acreage throughout the U.S. pecan belt (USDA, 2012; Wells, 2014). Georgia pecan producers planted at least 391,488 pecan trees and 6203 additional pecan hectares from 2010 to 2014 . The majority of these new pecan plantings are equipped with microsprinkler or drip irrigation systems (Wells, 2014).

Cultural practices that promote tree growth and vigor during the establishment phase are desirable for maximizing tree fruiting surface (Wood, 1996). Irrigation must be managed appropriately to achieve optimum tree growth and nut production, while ensuring minimal environmental impact. Methods of irrigation affect farm water use, which is a critical issue in many parts of the world, including the humid southeastern United States, where population growth and agricultural expansion are placing increasing pressure on the water supply. Historically, there have been no research based guidelines for managing irrigation of pecan trees during the establishment phase and prefruiting years. Smith et al. (2000) demonstrated improved pecan tree growth with mulch during orchard establishment by helping to conserve soil moisture. However, data regarding the water requirements of young pecan trees and the effect of irrigation on young pecan tree growth and establishment is lacking.

Patterson et al. (1990) found no effect of drip irrigation on young pecan tree diameter

Received for publication 19 Dec. 2016. Accepted for publication 25 Jan. 2017.

This work was supported by the Georgia Agricultural Commodity Commission for Pecans.

${ }^{1}$ Corresponding author. E-mail: lwells@uga.edu. following the first growing season in a humid climate with $92-124 \mathrm{~cm}$ of rainfall; however, growth was enhanced by irrigation in years 2 , 3 , and 4. Fereres et al. (1982) suggested that due to the uncertainty of the root zone of newly planted almond [Prunus dulcis (Mill.) D.A. Webb] trees in California, wetting of a large volume of soil moisture during the first year of growth was needed to supply adequate water to the developing root system. Method of irrigation can have a strong influence on root distribution. Low-volume irrigation results in a more vertically uniform root distribution near the emitters, whereas overhead irrigation produces more equally dense root systems in apple (Malus domestica Borkh.) (Huguet, 1976). Since root growth is directly correlated with shoot growth (Weaver and Himmel, 1929), root distribution as influenced by irrigation method can have important implications for tree growth and establishment.

Research is needed in the southeastern United States to evaluate the effects of drip and microirrigation on young pecan trees in a temperate, humid climate. The objectives of this study were to compare the effects of both methods of irrigation on growth and midday stem water potential of first through third leaf young pecan trees in the temperate climate of the southeastern United States and determine appropriate irrigation rates for pecan establishment in the region.

Study site, experimental design, and sampling

Studies were conducted at the University of Georgia Ponder Research Farm located near Tifton, GA, at $31^{\circ} 51^{\prime} \mathrm{N}$ latitude and $-83^{\circ} 64^{\prime} \mathrm{W}$ longitude. Orchard soils were

\section{Materials and Methods}

Tifton loamy sand (fine-loamy, silicieous, thermic Plinthic Paleudult). Trunks were protected with corrugated tree guards (A.M. Leonard, Piqua, $\mathrm{OH}$ ). The orchard was managed under commercial conditions according to University of Georgia Cooperative Extension recommendations (Hudson et al., 2012). A $3.7-\mathrm{m}$-wide vegetation-free strip was maintained with the herbicide glyphosate along the tree row in all plots. Row middles consisted of bermudagrass (Cynodon dactylon L.) sod.

Expt. 1. Bare-root 'Kanza' pecan trees grafted to 'Elliott' seedling rootstock were planted from nursery stock. Trees were planted in January 2014 at a spacing of $3 \mathrm{~m}$ between trees. All trees were irrigated with microsprinklers at varying rates depending on treatment. Microsprinklers were placed $\approx 0.3 \mathrm{~m}$ from the tree trunk. Trees were irrigated $3 \mathrm{~d}$ per week at $4 \mathrm{~h}$ per day from April to September. If rainfall exceeded $2.54 \mathrm{~cm}$ within a $24-\mathrm{h}$ period, irrigation was turned off for $3 \mathrm{~d}$. The following treatments were evaluated: 1) microsprinkler irrigation at $304 \mathrm{~L}$ per week (lpw) using a $25.36 \mathrm{~L}$ per hour (lph) microsprinkler head; 2) microsprinkler irrigation at $650 \mathrm{lpw}$ using a $54.13 \mathrm{lph}$ microsprinkler head; 3 ) nonirrigated control (NI). Treatments were arranged in a randomized complete block design with four blocks and each treatment represented once per block. All trees were located within a single orchard row. One nonirrigated guard tree was placed between each tree used in the study to avoid overlap of irrigation. Measurements were taken from each tree within each plot. Individual trees received the same treatments in consecutive years.

Midday stem water potential $(\psi)$ was determined using a pump-up pressure chamber (PMS Instruments, Albany, OR) by measuring the $\psi$ of leaves located near the trunk or a main scaffold branch, which had been enclosed in a foil-covered bag for $20 \mathrm{~min}$ (Begg and Turner, 1970). Measurements were made once per month between 1300 $1500 \mathrm{HR}$ from July to September in 2014, June to September in 2015, and May to September in 2016. One leaf per tree was measured on each sampling date to keep measurements within close temporal proximity.

Soil moisture was measured with a Field Scout TDR 300 Soil moisture meter (Spectrum Technologies, Aurora, IL) at $20-\mathrm{cm}$ depth within the wetted zone of microsprinklers $\approx 1.2 \mathrm{~m}$ from the base of the tree on each sampling date at the same time that stem $\psi$ was measured for each tree.

Stem diameter at $76.2 \mathrm{~cm}$ above the soil surface was measured on 9 Apr. 2014, 3 July 2014, 19 July 2014, 21 Sept. 2014, 6 Apr. 2015, 14 May 2015, 24 June 2015, 20 July 2015, 24 Aug. 2015, 14 Sept. 2015, 4 May 2016, 13 June 2016, 19 July 2016, and 21 Sept. 2016.

Leaf area, leaf length, and leaf width were measured 21 July 2014 and 7 Sept. 2016 using a LI-3000C portable leaf area meter (LI-COR Technologies, Lincoln, NE). Five leaves per tree were measured at each 

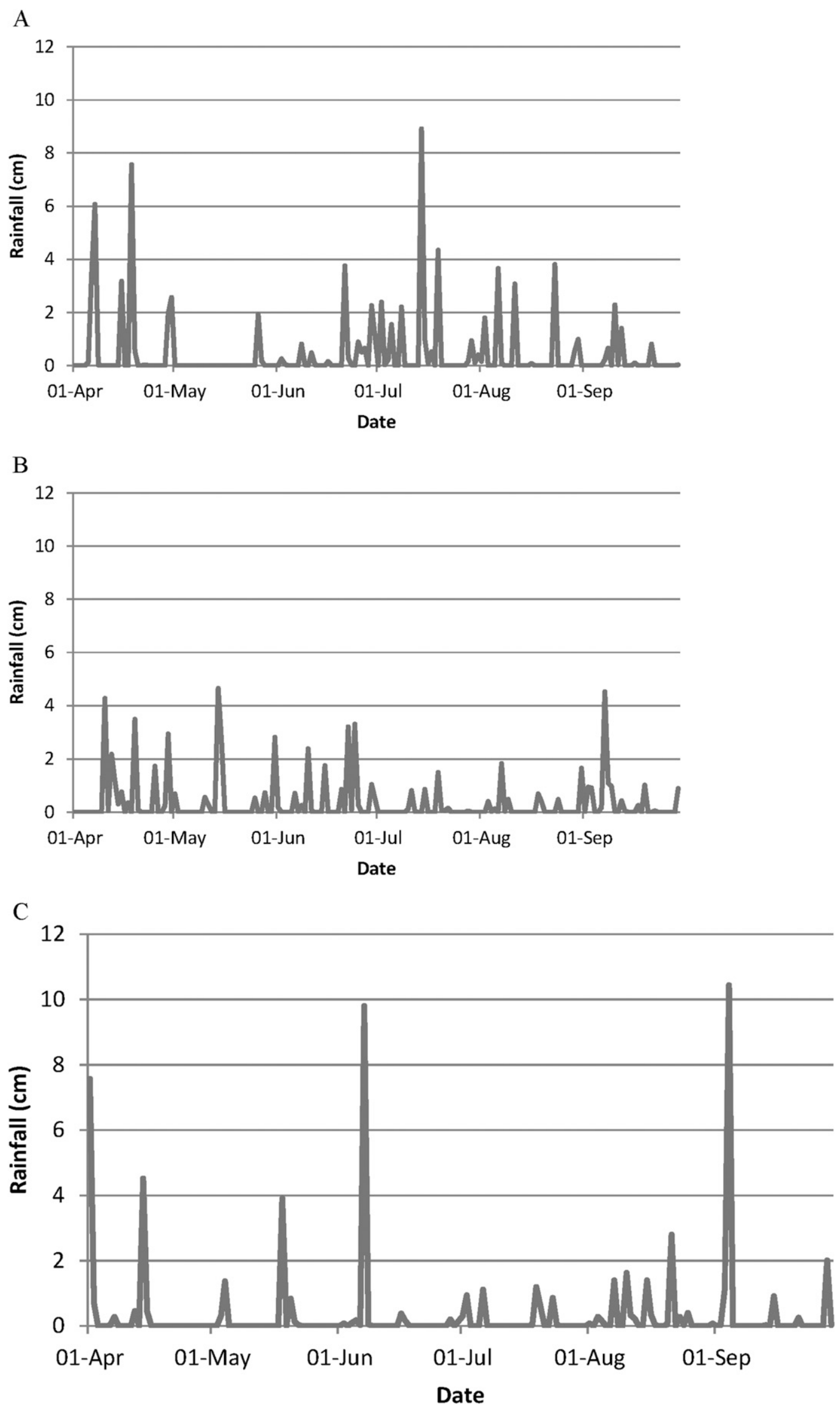

Fig. 1. Daily rainfall distribution from 1 Apr. to 30 Sept. during (A) 2014, (B) 2015, and (C) 2016 at the study site. 
sampling date. Leaf chlorophyll index (LCI) was measured 2 Sept. 2014 using a chlorophyll meter (SPAD-502; Minolta, Ramsey, NJ). All leaves measured for leaf area and LCI were fully expanded and selected from one pair of middle leaflets of compound leaves. Rainfall was recorded at a weather station located at the study site.

Expt. 2. Bare-root 'Desirable' pecan trees grafted to 'Elliott' rootstock were planted from nursery stock. Trees were planted in Jan. 2015 at a spacing of $12.2 \mathrm{~m} \times 12.2 \mathrm{~m}$. All trees received one application of dry, balanced fertilizer $(10 \mathrm{~N}-10 \mathrm{P}-10 \mathrm{~K})$ at a rate of $0.45 \mathrm{~kg} /$ tree in June 2015 and again in Apr. and June 2016. All trees were irrigated with microsprinkler or drip irrigation at varying rates depending on treatment. Microsprinklers were placed $\approx 0.3 \mathrm{~m}$ from the tree trunk. Trees were irrigated $3 \mathrm{~d}$ per week at $4 \mathrm{~h}$ per day from April to September. If rainfall exceeded $2.54 \mathrm{~cm}$ within a $24-\mathrm{h}$ period, irrigation was turned off for $3 \mathrm{~d}$. The following treatments were evaluated: 1) microsprinkler irrigation at $650 \mathrm{lpw}$ using a 54.13-lph microsprinkler head; 2) drip irrigation using seven $7.6 \mathrm{lph}$ emitters per tree supplying a total of $638 \mathrm{lpw}$. One emitter was placed $15 \mathrm{~cm}$ from the trunk on one side of the tree and three emitters were placed within $120 \mathrm{~cm}$ of the trunk on each side of the tree. Emitters $120 \mathrm{~cm}$ from the trunk were spaced $60 \mathrm{~cm}$ apart from each other on each side of the tree. 3) Drip irrigation using two 7.6-lph emitters supplying a total of $182 \mathrm{lpw}$. One emitter was placed $15 \mathrm{~cm}$ from the trunk of the tree and one emitter was placed within $120 \mathrm{~cm}$ of the trunk on one side of the tree. 4) NI. Treatments were arranged in a randomized complete block design with five blocks and each treatment represented once per block. Measurements were taken from each tree within each plot. Individual trees received the same treatments in consecutive years.

Soil moisture and midday stem $\psi$ were determined as above for Expt. 1. Measurements were made once per month between 1300 and 1500 HR from June to Sept. 2015 and May to Sept. 2016. One leaf per tree was measured on each sampling date to keep measurements within close temporal proximity.

Stem diameter at $76.2 \mathrm{~cm}$ above the soil surface was measured on 6 Apr. 2015, 14 May 2015, 24 June 2015, 20 July 2015, 24 Aug. 2015, 14 Sept. 2015, 4 May 2016, 13 June 2016, 19 July 2016, and 21 Sept. 2016.

Repeated measures analysis of variance (ANOVA) was used to measure treatment effects on stem $\psi$. ANOVA was used to measure treatment effects on trunk diameter growth, leaf area, leaf length, maximum leaf width, and chlorophyll index. Means were separated using Tukey's honestly significant difference test $(P \leq 0.05)$.

\section{Results and Discussion}

Rainfall during the study period was highly variable. The weather station on-site recorded 80,65 , and $60 \mathrm{~cm}$ of rainfall from
Apr. to Sept. for 2014, 2015, and 2016, respectively. Rainfall was not evenly distributed throughout the growing season for any of the years of study (Fig. 1), leading to intermittent periods of tree water stress.

Midday stem $\psi$ was higher $(P \leq 0.05)$, indicating less water stress on 'Kanza' trees in all irrigated treatments during 2 of the 3 years of study (Table 1). However, seasonlong water status was similar for both irrigation rates. Stem $\psi$ in the NI treatment ran well below that for trees under microsprinkler irrigation rates of 304 and 650 lpw at each sampling date in 2014 (Fig. 2). During 2015, stem $\psi$ was similar for all treatments in the 'Kanza' trees as a result of more frequent rainfall.

In contrast to Patterson et al. (1990), who saw no effect of irrigation on trunk diameter in the year of planting, trunk diameter growth in the current study was greater $(P \leq$ 0.05 ) for the irrigated 'Kanza' trees than for NI trees in the first and second years of establishment (Table 1). There was no difference in trunk diameter growth among irrigated trees during the first 2 years of study. The difference in trunk diameter growth for irrigated and NI trees during 2015 in the absence of a difference in stem $\psi$ between all treatments likely results from better root establishment in year 1 for irrigated trees, allowing them to respond with better early-season growth than NI trees in year 2. By the 3rd year of study, only the highest rate of irrigation generated a significant increase in trunk diameter growth over that of the control, suggesting the root system of NI trees was capable of better supporting tree growth and development by year 3 .

Although no root measurements were taken during the current study, the root system of young pecan trees is known to account for $\approx 60 \%$ to $70 \%$ of total tree dry weight (Wells, 2010) and the effects of irrigation on root growth of trees are known to be variable (Atkinson, 1980). Goode and Hyrycz (1964) found that irrigation increased apple root density in the top $15 \mathrm{~cm}$ but reduced density at $15-30 \mathrm{~cm}$ soil depth.
In contrast, Doichev (1977) found no effect of irrigation on apple root distribution. Variations between most such studies are attributed to soil type and climate (Gilman, 1990). Low-volume drip irrigation increases peach [Prunus persica (L.) Batsch] (Goode et al., 1978) and apple (Taylor, 1974) root density within a $30-40 \mathrm{~cm}$ radius of the drip emitter in arid climates. In temperate climates, drip irrigation placed $15 \mathrm{~cm}$ from the base of the trunk had no effect on root system depth in sugar maple (Acer sacharinum L.), honey locust (Gleditsia triacanthos L.), or pin oak (Quercus palustris Münchh.) (Costello and Paul, 1975), suggesting that root growth can occur at varying depths in temperate climates.

Leaf area, leaf length, and leaf width were measured for 'Kanza' trees in 2014 and 2016. Leaf area was greater $(P \leq 0.05)$ in both irrigated treatments as compared with the NI treatment in 2014 (Table 1). However, in 2016 , leaf area was greater in the $650 \mathrm{lpw}$ microsprinkler treatment than in the 304 lpw microsprinkler and NI treatments. There was no difference between 304 lpw and NI treatments in 2016 (Table 1).

Leaf length was greater $(P \leq 0.05)$ with $304 \mathrm{lpw}$ than with $650 \mathrm{lpw}$ in 2014 (Table 1). Microsprinkler irrigation at 304 and $650 \mathrm{lpw}$ led to increased $(P \leq 0.05)$ leaf length compared with NI. During 2016, both irrigation treatments increased leaf length compared with NI. Maximum leaf width was also increased by both irrigation treatments compared with NI in 2014; however, no differences in maximum leaf width were observed in 2016 (Table 1). Chlorophyll index measured in Sept. 2014 was higher $(P \leq 0.05)$ for both irrigated treatments than NI. The chlorophyll index provides an indirect measurement of photosynthesis and a relative estimate of vigor for these trees, suggesting potentially higher photosynthesis and vigor late in the growing season for irrigated trees.

Midday stem $\psi$ of first and second year 'Desirable' trees was higher $(P<0.05)$ for all irrigated treatments than for NI in 2015 and 2016. There was no difference in stem $\psi$ between irrigation treatments (Table 2). Trunk

Table 1. Mean midday stem water potential, trunk diameter growth, individual leaf area, leaf length, maximum leaf width, and chlorophyll index of 'Kanza' pecan trees under nonirrigated and microsprinkler irrigation treatments at 304 and $650 \mathrm{~L}$ of water applied per week (lpw) from 2014 to 2016 .

\begin{tabular}{|c|c|c|c|c|c|c|c|}
\hline $\mathrm{Yr}$ & Treatment & Stem $\psi$ & $\begin{array}{l}\text { Trunk diam } \\
\text { growth }(\mathrm{mm})\end{array}$ & $\begin{array}{c}\text { Leaf } \\
\text { area }(\mathrm{mm})\end{array}$ & $\begin{array}{c}\text { Leaf } \\
\text { length }(\mathrm{mm})\end{array}$ & $\begin{array}{c}\text { Maximum } \\
\text { leaf width }(\mathrm{mm})\end{array}$ & $\begin{array}{l}\text { Chlorophyll } \\
\text { index }\end{array}$ \\
\hline \multicolumn{8}{|c|}{2014} \\
\hline & 304 lpw & $-0.67 \mathrm{a}^{\mathrm{z}}$ & $2.2 \mathrm{a}$ & $26.8 \mathrm{a}$ & $10.3 \mathrm{a}$ & $4.1 \mathrm{a}$ & $21.1 \mathrm{a}$ \\
\hline & $650 \mathrm{lpw}$ & $-0.64 \mathrm{a}$ & $3.9 \mathrm{a}$ & $21.2 \mathrm{a}$ & $8.6 \mathrm{~b}$ & $3.8 \mathrm{a}$ & $24.7 \mathrm{a}$ \\
\hline & Nonirrigated & $-1.04 b$ & $0.8 \mathrm{~b}$ & $11.9 \mathrm{~b}$ & $6.3 \mathrm{c}$ & $2.8 \mathrm{~b}$ & $11.4 \mathrm{~b}$ \\
\hline \multicolumn{8}{|c|}{2015} \\
\hline & 304 lpw & $-0.63 \mathrm{a}$ & $10.5 \mathrm{a}$ & - & - & - & - \\
\hline & $650 \mathrm{lpw}$ & $-0.65 \mathrm{a}$ & $14.4 \mathrm{a}$ & - & - & - & - \\
\hline & Nonirrigated & $-0.66 \mathrm{a}$ & $4.0 \mathrm{~b}$ & - & - & - & - \\
\hline \multicolumn{8}{|c|}{2016} \\
\hline & 304 lpw & $-0.83 \mathrm{a}$ & $15.1 \mathrm{ab}$ & $27.7 \mathrm{~b}$ & $10.6 \mathrm{a}$ & $3.8 \mathrm{a}$ & - \\
\hline & $650 \mathrm{lpw}$ & $-0.84 \mathrm{a}$ & $18.7 \mathrm{a}$ & $32.9 \mathrm{a}$ & $11.3 \mathrm{a}$ & $4.3 \mathrm{a}$ & - \\
\hline & Nonirrigated & $-0.97 \mathrm{~b}$ & $9.3 \mathrm{~b}$ & $22.5 \mathrm{~b}$ & $8.7 \mathrm{~b}$ & $3.6 \mathrm{a}$ & - \\
\hline
\end{tabular}

${ }^{\mathrm{z}}$ Means followed by the same letter within each year are not different at $P<0.05$ by Tukey's honestly significant difference test. 


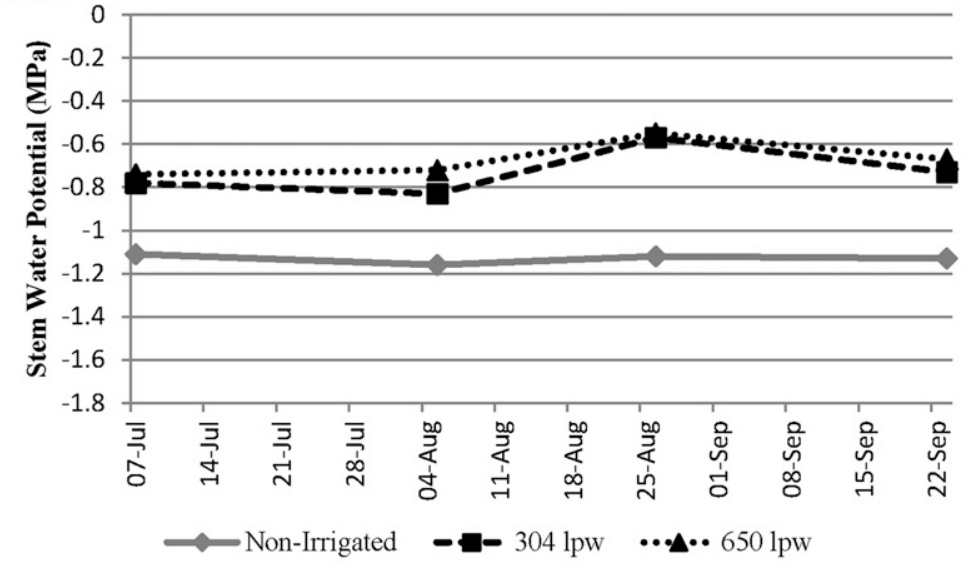

2015

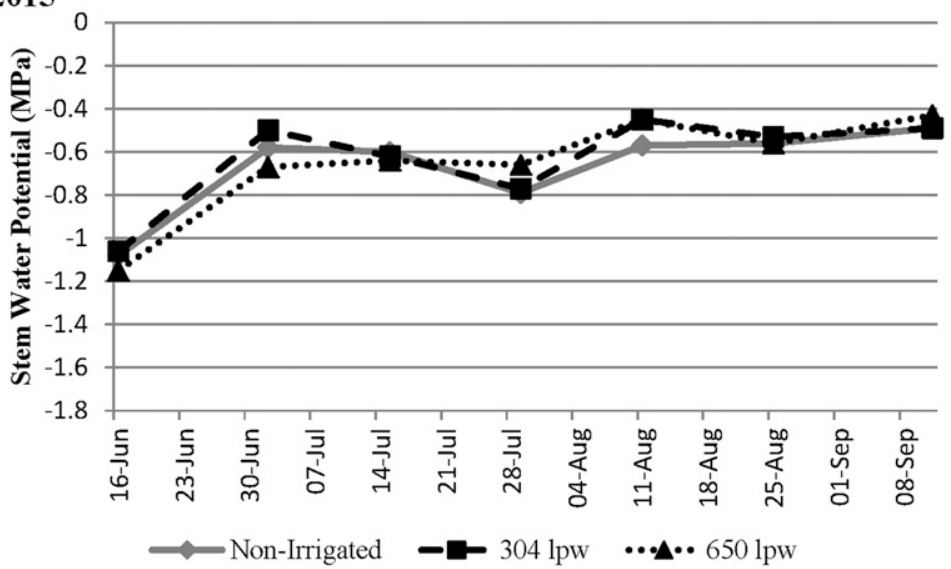

2016

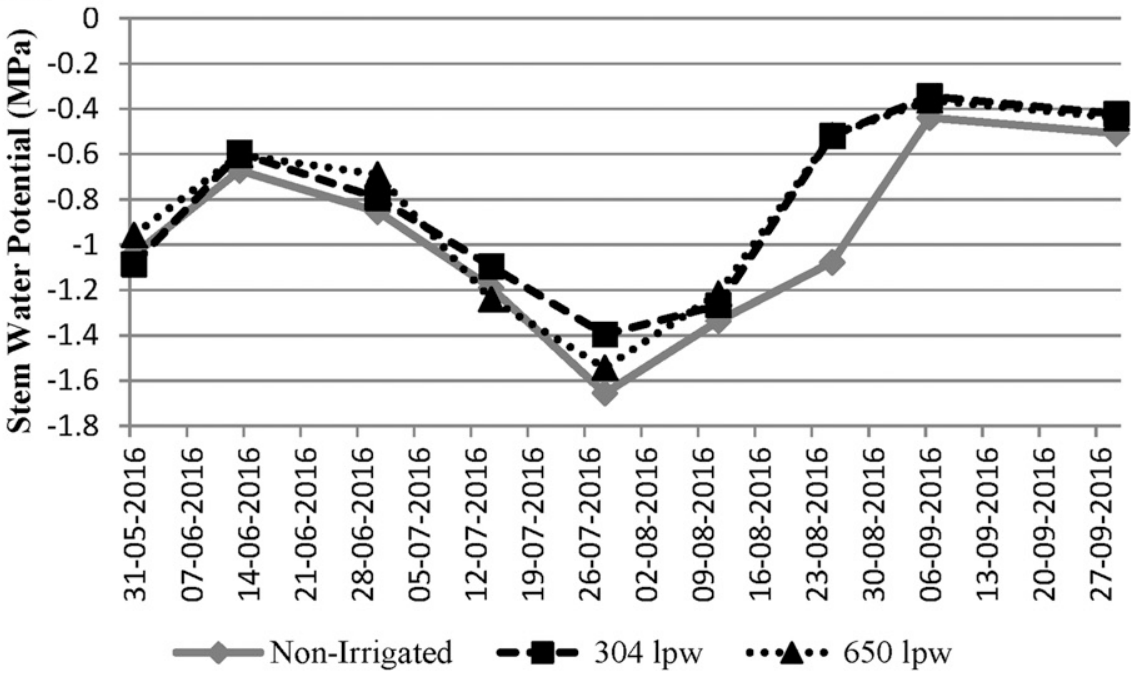

Fig. 2. Mean midday stem water potential $(\psi)$ of young 'Kanza' pecan trees irrigated with microsprinklers at 304, $650 \mathrm{lpw}$, and nonirrigated during 2014, 2015, and 2016.

diameter growth of first year 'Desirable' trees was greater $(P \leq 0.05)$ in all irrigated treatments compared with NI in 2015, with no difference in growth among irrigated trees (Table 2). Drip irrigation at $638 \mathrm{lpw}$ led to increased $(P \leq 0.0 .5)$ trunk diameter growth compared with NI but not when compared with the other irrigation treatments in 2016. There was no difference in trunk diameter growth between the remaining irrigation treatments and NI. This may be explained by the changes observed in stem $\psi$ over the course of the growing season as affected by the variable seasonal rainfall (Figs. 1 and 3).

These results suggest that irrigation is beneficial to the growth, vigor, and alleviation of water stress on young pecan trees in the establishment phase grown in the temperate region of the southeastern United States. However, the magnitude of those benefits will vary from year to year based on the amount and frequency of rainfall.
Table 2. Mean midday stem water potential and trunk diameter growth of 'Desirable' pecan trees under microirrigation (650 lpw), drip irrigation (182 lpw) and (638 lpw), and nonirrigated treatments in 2015 and 2016.

\begin{tabular}{cccc}
\hline Yr & Treatment & Stem $\psi$ & $\begin{array}{c}\text { Trunk diam } \\
\text { growth (mm) }\end{array}$ \\
\hline 2015 & Drip (182 lpw) & $-0.64 \mathrm{a}^{\mathrm{z}}$ & $4.46 \mathrm{a}$ \\
& Drip (638 lpw) & $-0.65 \mathrm{a}$ & $4.99 \mathrm{a}$ \\
& Microsprinkler & $-0.66 \mathrm{a}$ & $4.94 \mathrm{a}$ \\
(650 lpw) & & \\
& Nonirrigated & $-0.85 \mathrm{~b}$ & $2.36 \mathrm{~b}$ \\
& & & \\
& Drip (182 lpw) & $-0.69 \mathrm{a}$ & $18.7 \mathrm{ab}$ \\
& Drip (638 lpw) & $-0.68 \mathrm{a}$ & $21.1 \mathrm{a}$ \\
Microsprinkler & $-0.73 \mathrm{a}$ & $17.5 \mathrm{ab}$ \\
(650 lpw) & & \\
Nonirrigated & $-0.87 \mathrm{~b}$ & $10.6 \mathrm{~b}$ \\
\hline
\end{tabular}

${ }^{\mathrm{z}}$ Means followed by the same letter within each year are not different at $P<0.05$ by Tukey's honestly significant difference test.

Irrigation had a significant effect on growth and stem water potential in the year of planting for both 'Kanza' and 'Desirable' trees, with increases in stem diameter growth ranging from $89 \%$ to $388 \%$ compared with NI trees (Tables 1 and 2). This likely resulted from the inability of first leaf trees to be supported by a limited root system without irrigation. The increased ability of NI trees to use the soil moisture supplied through rainfall in the humid conditions of this study as the trees aged and the root system expanded is reflected in similarities of trunk diameter growth among treatments in 2016 for 'Kanza' (Table 1) and 2015 for 'Desirable' (Table 2). This is supported by Ponder and Kenworthy (1976) who found sufficient soil moisture for root growth well beyond the drip emitter in a temperate climate.

The defining of appropriate irrigation rates for young pecan trees can be of benefit to their establishment and the stewardship of valuable water resources. These results suggest that, under the conditions of this study, there is no difference in young pecan tree growth and vigor for microsprinklerirrigated trees at $304 \mathrm{lpw}$ compared with $650 \mathrm{lpw}$ from the year of planting through the third leaf. Similarly, drip irrigation at 182 lpw appears to result in equal tree growth compared with both drip and microsprinkler irrigation at over 600 lpw. Thus, it appears that drip irrigation can reduce irrigation water application volume for young pecan trees grown under southeastern U.S. conditions. However, it is possible that microsprinklers may be useful on more coarse soil textures. The similarity in tree growth with such drastic variations in water volume for microsprinkler vs. drip irrigation may be explained by differences in irrigation efficiency as affected by higher evaporation rates for microsprinklers compared with drip. Bryla et al. (2003) found microsprays had lower irrigation efficiency than other systems in young peach orchards due to high rates of soil evaporation following irrigation. Some studies have suggested that 

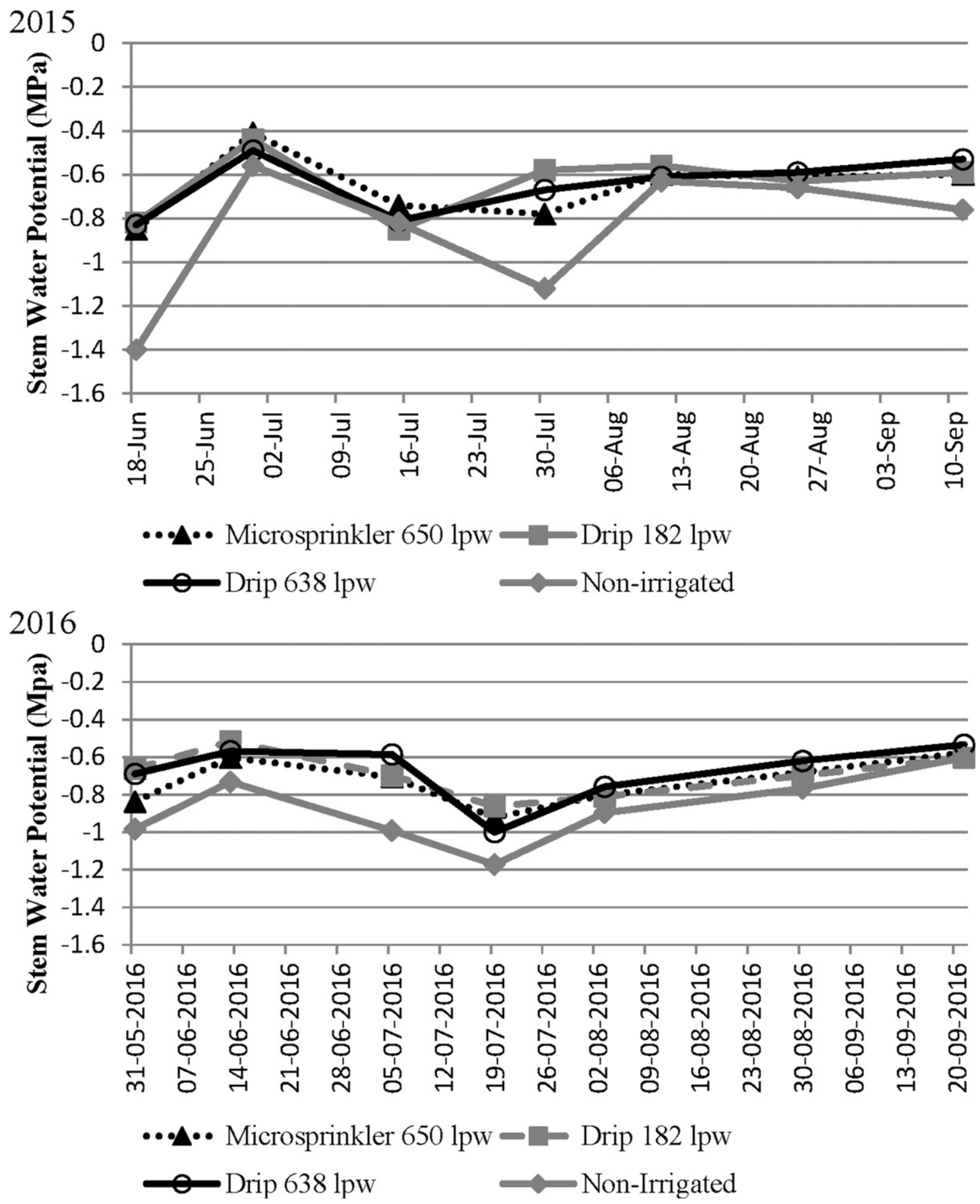

Fig. 3. Mean midday stem water potential $(\psi)$ of young 'Desirable' pecan trees irrigated with microsprinklers at 650 lpw, drip irrigation at 182 lpw, drip irrigation at $638 \mathrm{lpw}$, and nonirrigated during 2015 and 2016.

drip irrigation may be unsuitable for coarsetextured soils due to poor lateral water movement (Bryla et al., 2003). Andreu et al. (1997) stated that drip irrigation could not meet the water demand of almond on gravelly, sandy loam soil. Similarly, Schwankl et al. (1999) reported enhanced vegetative growth and yield of almond with microspray irrigation compared with drip on a similar soil.

The variation observed in the current study for both water stress and trunk diameter growth of young pecan trees suggests that the required irrigation rate for optimal tree growth will vary in the humid, temperate region of the southeastern United States with rainfall both within and between growing seasons. Intermittent periods of drought during the growing season in a temperate climate can be highly limiting to the growth of nonirrigated trees in this critical phase of orchard establishment, which has the potential to affect their precocity. Thus, it appears that irrigation of young trees in this region may not always be necessary for tree survival but would provide a major advantage toward acceleration of tree establishment and possibly, as a result, nut production. Although required irrigation rates may vary considerably with rainfall in a humid climate, it appears that a microsprinkler rate of 304-378 lpw and a drip irrigation rate of $182 \mathrm{lpw}$ are suitable for maximum growth of first through third leaf pecan trees on loamy sand soil in the southeastern United States. However, excessive dry 
periods, particularly on coarse-textured soils, may create a periodic need for as much as 650 lpw with microsprinklers.

\section{Literature Cited}

Andreu, L., J.W. Hopmans, and L.J. Schwankl. 1997. Spatial and temporal distribution of soil water balance of a drip irrigated almond tree. Agr. Water Mgt. 35:123-146.

Atkinson, D. 1980. The distribution and effectiveness of the roots of tree crops. Hort. Rev. 2: 424-490.

Begg, J.E. and N.C. Turner. 1970. Water potential gradients in field tobacco. Plant Physiol. 46: 343-346.

Bryla, D.R., J. Gartung, T. Trout, J.E. Ayars, and R.S. Johnson. 2003. Growth and production of young peach trees irrigated by furrow, microspray, surface drip, or subsurface drip systems. HortScience 38:112-116.

Costello, L. and J.L. Paul. 1975. Moisture relations in transplanting container plants. HortScience 10:371-372.

Doichev, K. 1977. Root distribution of M7 clonal apple rootstocks grafted with Golden Delicious as affected by different methods and rates of irrigation. Nauka 14:19-24.

Fereres, E., D.A. Martinich, T.M. Aldrich, J.R. Castel, E. Holzapfel, and H. Schulbach. 1982. Drip irrigation saves money in young almond orchards. Calif. Agr. 36(9):12-13.

Gilman, E.F. 1990. Tree root growth and development: II. Response to culture, management, and planting. J. Environ. Hort. 8:220-227.

Goode, J.E. and K.J. Hyrycz. 1964. The response of Laxton's superb apple trees to different soil moisture conditions. J. Hort. Sci. 39:254-276.

Goode, J.E., K.H. Higgs, and K.J. Hyrycz. 1978. Trickle irrigation of apple trees and the effect of liquid feeding with $\mathrm{NO}_{3}$ and $\mathrm{K}^{+}$compared with normal manuring. J. Hort. Sci. 53:307-316.

Hudson, W., J. Brock, S. Culpepper, and L. Wells. 2012. Georgia pecan pest management guide. Univ. Georgia Coop. Ext. Bull. 841.

Huguet, J.G. 1976. Influence of localized irrigation on the rooting of young apple trees. Ann. Agron. 27:343-361.

Patterson, M.G., G. Wehtje, and W.D. Goff. 1990. Effects of weed control and irrigation on the growth of young pecans. Weed Technol. 4:892-894.
Ponder, H.G. and A.L. Kenworthy. 1976. Trickle irrigation of shade trees growing in the nursery. J. Amer. Soc. Hort. Sci. 101:104-107.

Schwankl, L.J., J.P. Edstrom, J.W. Hopmans, L. Andreu, and K.S. Koumanov. 1999. Microsprinklers wet larger soil volume; boost almond yield, tree growth. Calif. Agr. 53:39-43.

Smith, M.W., B. Carroll, and B.S. Cheary. 2000. Mulch improves pecan tree growth during orchard establishment. HortScience 35:192-195.

Taylor, A. 1974. Trickle irrigation experiments in the Goulburn Valley. Victorian Hort. Digest 61:4-8.

U.S. Department of Agriculture. 2012. Noncitrus fruits and nuts: 2011 summary. Natl. Agr. Stat. Serv., U.S. Dept. Agr., Washington, DC.

Weaver, J.E. and W.J. Himmel. 1929. Relation between the development of root system and shoot under long and short-day illumination. Plant Physiol. 4:435-437.

Wells, M.L. 2010. Influence of aldicarb on growth and fruiting of pecan transplants. HortTechnology 20:556-559.

Wells, M.L. 2014. Pecan planting trends in Georgia. HortTechnology 24:475-479.

Wood, B.W. 1996. Establishing pecan transplants. HortTechnology 6:276-279. 